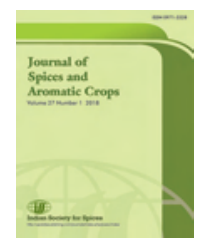

\title{
Current status of viral diseases affecting black pepper and cardamom
}

\author{
A I Bhat ${ }^{1 *}$, C N Biju ${ }^{1}$, V Srinivasan², S J Ankegowda ${ }^{2} \&$ K S Krishnamurthy ${ }^{2}$ \\ ${ }^{1}$ Division of Crop Protection, ${ }^{2}$ Division of Crop Production and Post Harvest Technology, \\ ICAR-Indian Institute of Spices Research, Kozhikode-673 012, Kerala. \\ *E-mail: aib65@yahoo.co.in
}

Received 29 November 2017; Revised 26 April 2018; Accepted 28 April 2018

\begin{abstract}
Black pepper and cardamom are the important spice crops grown in India and other countries. Viruses are one of the major yield limiting factors in both these spice crops. Viral diseases spread at a faster rate in these spices, as they are vegetatively propagated. Lack of sensitive detection methods has led to the widespread distribution of viral diseases in all black pepper and cardamom growing regions. The viruses infecting these two spice crops have now been identified; characterized and sensitive diagnostics developed. Integration of various approaches like use of resistant varieties, virus-free planting materials, vector control and cultural methods are required for the management of viral diseases. Rejuvenation of viral disease affected black pepper plantations through proper soil and plant health management were proved to be successful. The present review deals with characterization, diagnosis and management of viral diseases affecting black pepper and cardamom.

Keywords: Banana bract mosaic virus, Cardamom mosaic virus, Cucumber mosaic virus, Piper yellow mottle virus, characterization, detection, management

Abbreviations: BBrMV: Banana bract mosaic virus, CdMV: Cardamom mosaic virus, CMV: Cucumber mosaic virus, FYM: Farm yard manure, LAMP: Loop-mediated isothermal amplification, MSL: Mean sea level, ORF: Open reading frame, PGPR: Plant growth promoting rhizobacteria, PCR: Polymerase chain reaction, PYMoV: Piper yellow mottle virus, RT-PCR: Reverse transcription polymerase chain reaction, RT-LAMP: Reverse transcription-Loop-mediated isothermal amplification
\end{abstract}

\section{Introduction}

Black pepper (Piper nigrum L.), the "King of Spices", is native to the tropical evergreen forests of Western Ghats of India. It is used for different purposes such as culinary seasoning, ingredient of food items, and also in medicine (Ravindran 2000). Although wilt diseases caused by oomycetes and nematodes continue to be the major diseases infecting black pepper, the disease caused by viruses is also becoming important in recent times due to its systemic nature and resultant yield loss. Virus induced symptoms are known by different names such as mosaic, little leaf, wrinkled leaf and stunted disease in different black pepper growing countries. Cardamom (Elettaria cardamomum Maton), adorns the unique position as the 
"Queen of Spices" owing to its good aroma and flavour. Cardamom is a perennial, rhizomatous monocot, representing the family Zingiberaceae. Like black pepper it is also originated from evergreen forests of the Western Ghats of India. The economic part of the cardamom is the dried ripe fruits (known as capsules). It is generally cultivated in the mountainous tracts at elevations of $800-1300$ $\mathrm{m}$ above MSL especially as an under crop in the forest lands (Ravindran 2002). Cardamom is suffered by several oomycetous, fungal, viral and nematode-induced diseases. Mosaic and chlorotic streak are the important viral diseases affecting cardamom in India. Primary spread of viruses occurs by the use of infected planting materials. Hence, it is important to employ sensitive techniques to detect viruses in the plant system so that the infected materials could be identified and eliminated which further aids in the selection of virus-free healthy material for subsequent propagation.

\section{Viral disease of black pepper}

\section{Occurrence and symptoms}

Viral disease also known as stunt disease has been reported from black pepper growing countries such as Brazil, India, Indonesia, Malaysia, Philippines, Sri Lanka, Thailand and Vietnam (Paily et al. 1981; Lockhart et al. 1997; Sarma et al. 2001; de Silva et al. 2002; Bhat et al. 2003). In India, higher incidence (29 to $45 \%$ ) and severity of the disease was noticed in black pepper plants grown at higher altitudes (Bhat et al. 2005c). Mosaic, mottling and formation of malformed leaves with reduced size are the most obvious symptoms for identifying the disease in the field (Fig. 1). When infection becomes severe, leaves become rough, leathery, and narrow in the form of a sickle. The length between nodes of the stem reduces drastically leading to stunting of the plants. However, under certain circumstances, the virus affected plants do not produce any visible external
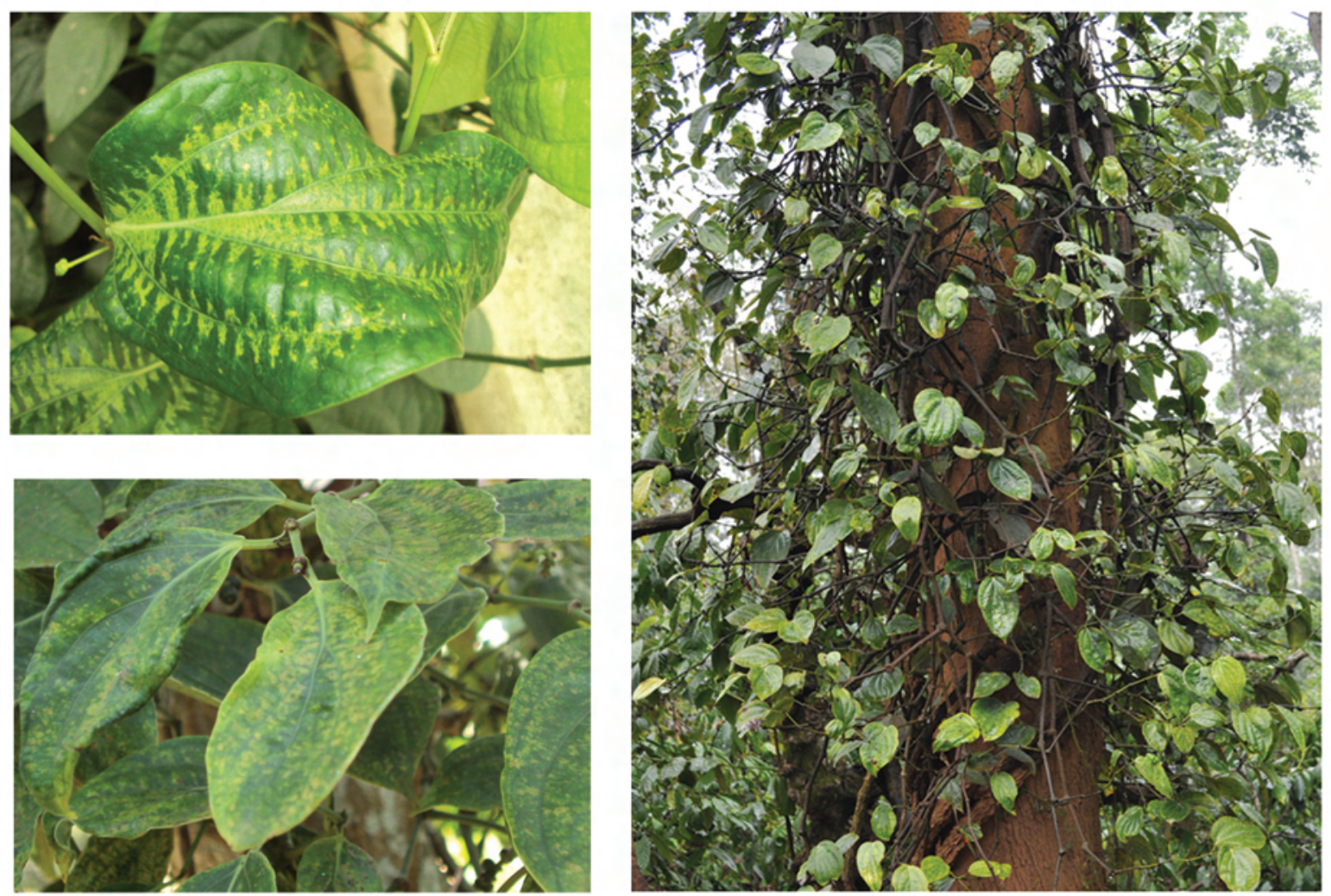

Fig. 1. Symptoms of viral disease affected black pepper 
symptoms. Recent studies have indicated that, severity of the disease increases under abiotic stress like nutrition and temperature (Umadevi et al. 2016).

\section{Causal viruses}

Two viruses namely, Cucumber mosaic virus (CMV) and Piper yellow mottle virus (PYMoV) have been reported to be associated with the disease. Of these, CMV contains isometric particles with a single stranded RNA genome that belongs to the genus, Cucumovirus (Family: Bromoviridae) (Palukaitis et al.1992). Besides black pepper, CMV is also reported to infect other Piper species such as $P$. betle (betelvine) and P. longum (Indian long pepper). Coat protein gene sequence studies of the CMV infecting different Piper species showed that they belong to CMV subgroup IB (Bhat et al. 2005a; Hareesh et al. 2006). Recently, full genome sequence of the CMV infecting black pepper revealed that it comprises three RNA species namely, RNA1, RNA2 and RNA3 with 3429, 3049 and 2237 nucleotides respectively (Revathy \& Bhat 2017). RNA1 comprised of one open reading frame (ORF) that code for viral replicase protein. Two ORFs of the RNA 2 codes for the replicase (2a) and viral suppressor protein (2b) while two ORFs of the RNA3 codes for movement protein (MP) and coat protein (CP) with 279 and 218 amino acids respectively. Of the five genes of the CMV, the $3 \mathrm{~b}$ gene coding for coat protein has the highest identity among the CMV subgroups (80-99\%) while the gene $2 \mathrm{~b}$ showed the minimum identity (51-95\%). Phylogenetic analyses also showed that, CMVblack pepper isolate falls in subgroup IB.

PYMoV, a circular double stranded DNA virus with bacilliform particle morphology belongs to the genus, Badnavirus under the family Caulimoviridae. Besides black pepper, PYMoV is also known to infect betelvine, Indian long pepper and many other related species (Siju et al. 2008; Bhat et al. 2014). Initially the virus was identified based on the particle morphology, transmission, serology and partial nucleotide sequence of the reverse transcriptase (RT)/RNase $\mathrm{H}$ region of the virus (Lockhart et al. 1997; de Silva et al. 2002; Bhat et al. 2003; Hareesh \& Bhat, 2008). The full genome sequence of virus isolates infecting black pepper, betelvine and Indian long pepper showed that the length of the genome varied from 7559 to 7584 nucleotides and all four isolates possessed four ORFs. The four ORFs could potentially encode proteins of 16, 17, 219 and $17 \mathrm{kDa}$, respectively (Hany et al. 2014; Deeshma \& Bhat 2015). The ORF III of the PYMoV codes a polyprotein with homology to different proteins such as viral movement, trimeric dUTPase, zinc finger, aspartic protease, reverse transcriptase and RNase $\mathrm{H}$ whereas, proteins coded by ORF I, II and IV did not show homology to any known proteins. PYMoV showed $39 \%$ to $56 \%$ identity with other badnaviruses. In phylogenetic analysis all PYMoV isolates formed a single cluster separated from other badnaviruses (Deeshma \& Bhat 2015).

\section{Transmission}

The primary means of spread of both viruses occur through vegetative means. Of the two viruses, CMV has very broad host range and could be mechanically transmitted to large number of hosts (de Silva et al. 2001; Sarma et al. 2001). In contrast, PYMoV infects only Piper spp and could be transmitted semipersistently through mealybugs such as Ferrisia virgata and Planococcus citri (Lockhart et al. 1997; Bhat et al. $2003 ; 2005$ b), by black pepper lace bug (de Silva et al. 2002) and is also transmitted through seeds (Hareesh \& Bhat 2010; Deeshma \& Bhat 2014). However, seed transmission may not have much significance in the spread of PYMoV in plantations as black pepper is mainly propagated through vegetative means, however, this can cause considerable interference in breeding experiments. Seeds can be infected when one of the parents is infected as there is a chance for the pollens and ovary to be infected.

\section{Diagnosis and detection}

\section{Symptoms}

Symptoms are one of the good criteria for diagnosis of viral diseases. But sometimes based on environmental and growth conditions, 
infected plants may appear apparently healthy without symptoms. Our studies have shown that, virus infected plants exhibit symptoms when exposed to abiotic factors such as high temperature and poor nutrient status of the soil. Hence, soil and plant health play a major role in symptom appearance and severity of the disease. When virus infected but asymptomatic plants were subjected to temperature stress $\left(35^{\circ} \mathrm{C}\right)$, plants started showing symptoms within 10 days of exposure (Umadevi et al. 2016). Thus, plants that do not show symptoms cannot be always considered as virus-free. Laboratory-based methods such as polymerase chain reaction (PCR) or loopmediated isothermal amplification (LAMP) is required to ascertain the presence or absence of virus in the plant to identify virus-free plants for propagation.

\section{Polymerase chain reaction (PCR)}

PCR and reverse transcription (RT)-PCR (RT$\mathrm{PCR}$ ) methods were reported for the detection of PYMoV and CMV infections respectively in black pepper (Lockhart et al. 1997; de Silva et al. 2002; Siju et al. 2008; Hareesh \& Bhat 2008; Bhat et al. 2009). List of primers reported for the detection of viruses by different workers is presented in Table 1. De Silva et al. (2002) and Hareesh \& Bhat (2008) reported simple total DNA isolation method from black pepper which can be used as template for detection of PYMoV while Siju et al. (2007) reported an efficient total RNA isolation method from black pepper that enhanced sensitivity of detection of CMV in black pepper (Fig. 2). Using PCR, Bhat et al. (2009) reported presence of PYMoV in symptomless plants of black pepper indicating the need to use sensitive methods to identify virus-free plants (Fig. 3). Further, a multiplex RT-PCR (mRT-PCR) method was reported for the combined detection of CMV and PYMoV in black pepper (Bhat \& Siju 2007). The method involved combined isolation of both RNA and DNA from infected black pepper samples to use as template in $\mathrm{mRT}$-PCR reaction. Primers

Table 1. Oligonucleotide primers used for the detection of CMV and PYMoV infecting black pepper through PCR/RT-PCR

\begin{tabular}{|c|c|c|c|c|c|}
\hline Virus & $\begin{array}{l}\text { Primer } \\
\text { name }\end{array}$ & Sequence $\left(5^{\prime}-------3^{\prime}\right)$ & $\begin{array}{l}\text { Region } \\
\text { amplified }\end{array}$ & $\begin{array}{l}\text { Amplicon } \\
\text { size (bp) }\end{array}$ & Reference \\
\hline \multirow[t]{4}{*}{ CMV } & AIB 1 & ATGGACAAATCTGAATCAAC & Coat protein & 650 & Bhat et al. \\
\hline & AIB 2 & TCAAACTGGGAGCACCC & gene & & $\begin{array}{l}\text { 2005a; Bhat \& } \\
\text { Siju } 2007\end{array}$ \\
\hline & AIB 35 & TAACAGGACTAGGGATCG & & 450 & $\begin{array}{l}\text { Hareesh \& } \\
\text { Bhat, 2008; }\end{array}$ \\
\hline & AIB 36 & CAGCTGGTCTTGATAATAG & ORF 1 & & $\begin{array}{l}\text { Bhat \& Siju } \\
\text { 2007; Bhat et } \\
\text { al. } 2009\end{array}$ \\
\hline \multirow[t]{6}{*}{ PYMoV } & SCBV-R1 & СТССТTСАТСТССТСAAGAAGССТ & & 700 & De Silva et al. \\
\hline & Badna $1 \mathrm{R}$ & CCAAAGCTCTGATAGCAGAC & ORF I & & 2002 \\
\hline & AIB 104 & CTATATGAATGGCTAGTGATG & ORF III & 450 & Bhat et al. 2009 \\
\hline & AIB 105 & TTCCTAGGTTTGGTATGTATG & & & \\
\hline & AIB 225 & TTTGTCAAGCCAAGAGACCAC & ORF II & 350 & Sasi \& Bhat \\
\hline & AIB 226 & TTGAGTGATTTGGTCCTCCAC & & & 2018 \\
\hline
\end{tabular}




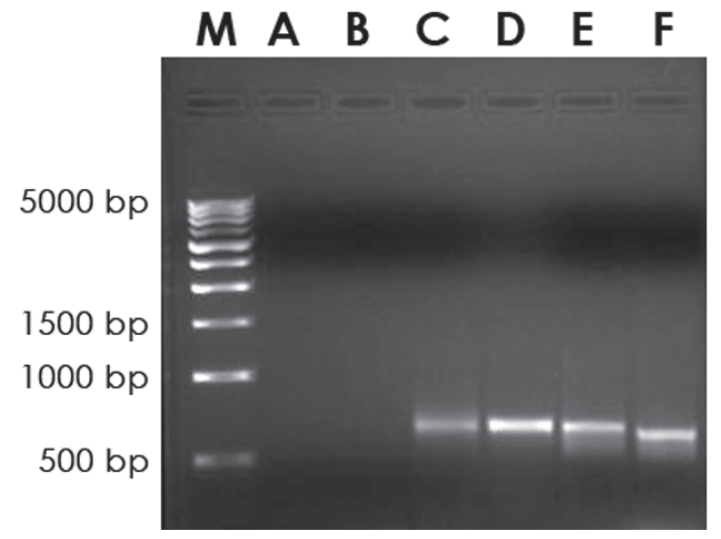

Fig. 2. Detection of Cucumber mosaic virus in black pepper through RT-PCR. Lane M: $1 \mathrm{~kb}$ ladder; Lane A: Healthy control (known healthy plant); Lanes B-E: test plants Lane F: Positive control (known infected plant)

designed for the CMV coat protein gene and ORF I of PYMoV were employed in mRT-PCR.

\section{Real-time PCR}

A real-time PCR based on SYBR Green for the detection of PYMoV and SYBR Green based real-time RT-PCR for the detection of CMV infecting black pepper have been reported. The method involved isolation of template nucleic acid (both DNA and RNA) from infected plants (Bhat \& Siju 2007) and used primers targeted to the conserved region in coat protein (for CMV) and ORF III (for PYMoV) (Fig. 4) (Bhat $\&$ Siljo 2014). The utility of assay was shown by testing large number of black pepper from different agro-climatic regions and related species such as $P$. betle, $P$. longum and $P$. colubrinum.

\section{Loop-mediated isothermal amplification (LAMP)}

LAMP is a quick, sensitive, low cost diagnostic method that can be used for detection of pathogens including viruses. A rapid and sensitive detection assay based on LAMP for the detection of PYMoV and reverse transcriptase (RT)-LAMP (RT-LAMP) for the detection of CMV infecting black pepper was reported (Bhat et al. 2013). Each LAMP method comprised of primers such as F3, B3, FIP, BIP, $\mathrm{LF}$ and $\mathrm{BF}$ designed to the conserved ORF III of PYMoV and coat protein gene of CMV. The combined DNA and RNA isolated from infected black pepper plants served as template in the assay. The visual detection of LAMP reaction was done by checking turbidity of the reaction tube by naked eye and green fluorescence under UV light and also by agarose gel electrophoresis (Fig. 5). Both methods (LAMP and RT-LAMP) were successful in the detection of both viruses in diseased plants (Fig. 5). LAMP was 100 times more sensitive compared to PCR. However, when compared to real-time PCR, LAMP was 10 times less sensitive in the detection of both viruses. Both LAMP and RTLAMP assays were able to detect respective viruses in large number of black pepper samples representing different agro-climatic regions (Bhat et al. 2013).

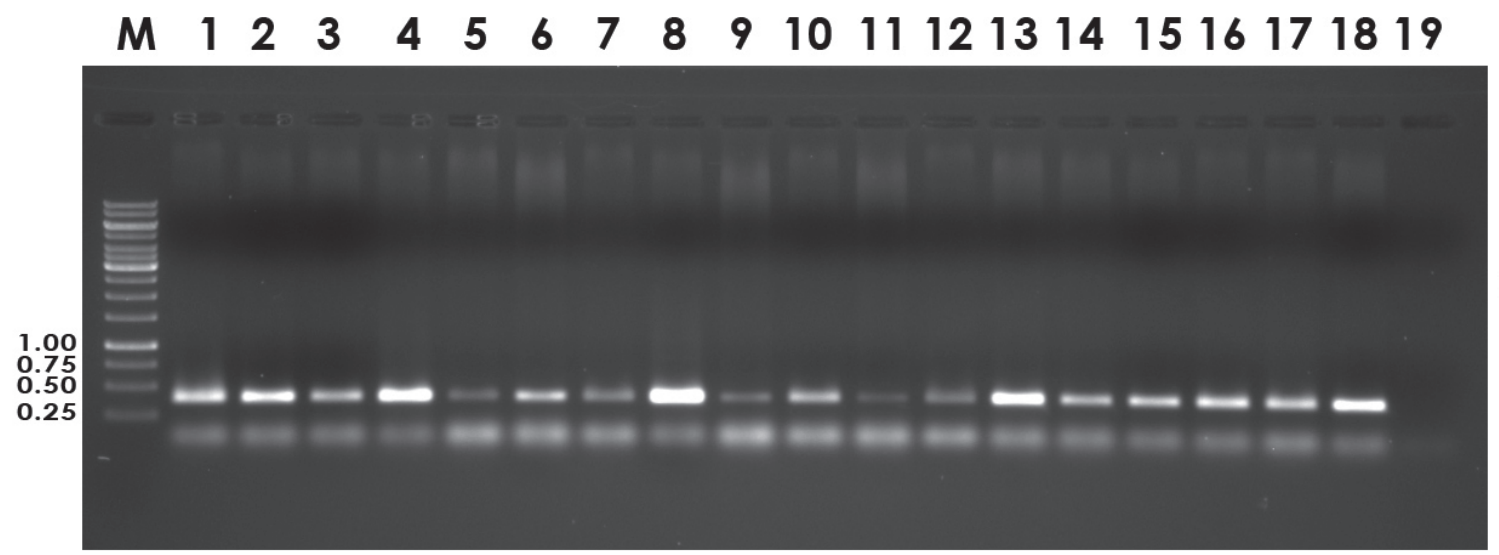

Fig. 3. PCR based testing of black pepper plants for Piper yellow mottle virus (PYMoV) infection. Lane M represents marker, lane 1 and 19 represent positive and negative controls while lanes 2-18 were test plants 

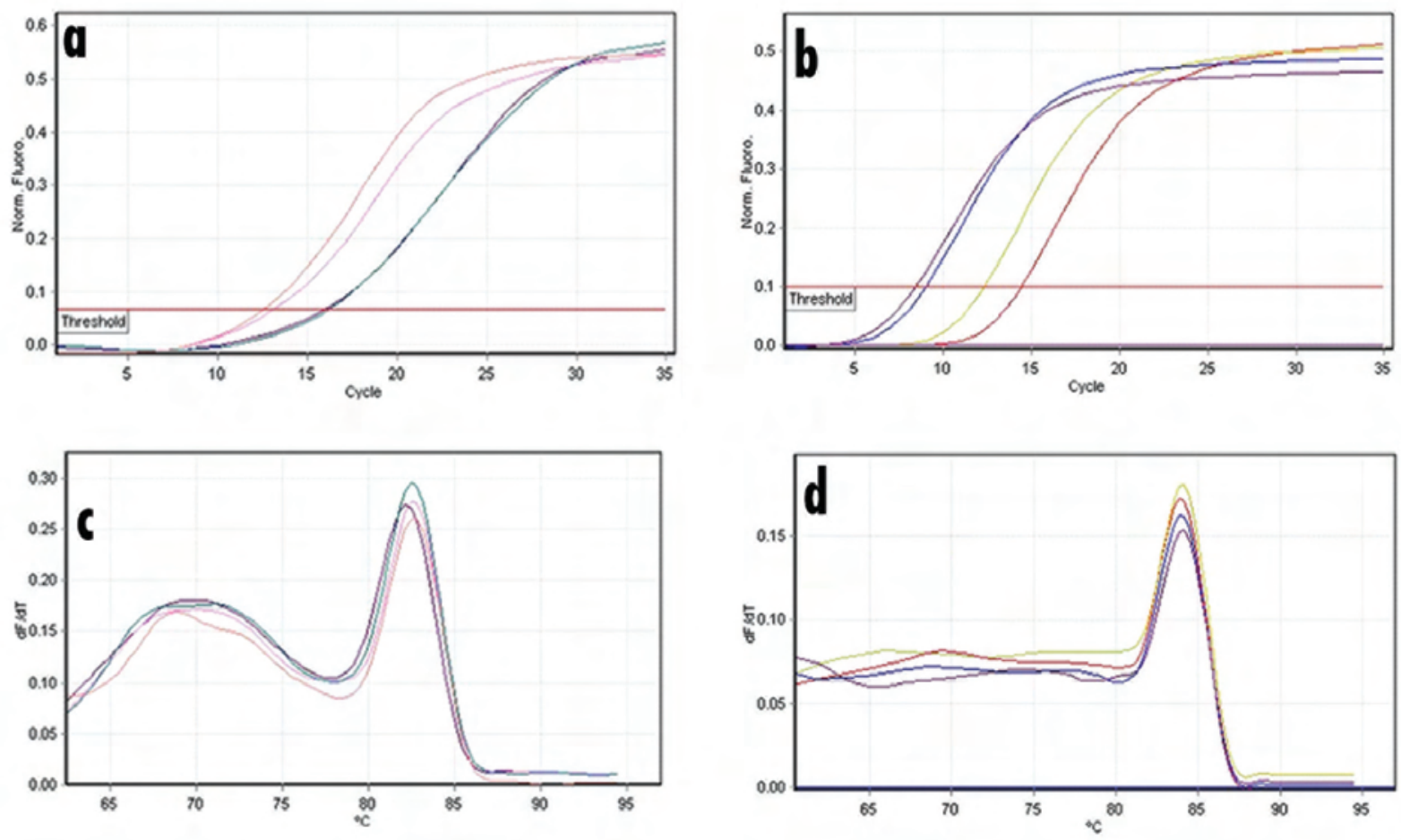

Fig. 4. Development of real-time PCR and real-time RT-PCR for the detection of Piper yellow mottle virus and Cucumber mosaic virus in black pepper: $(a, b)$ amplification curves of real-time PCR and realtime RT-PCR obtained with infected samples; (c, d) melt curve analysis of corresponding realtime PCR and real-time RT-PCR products

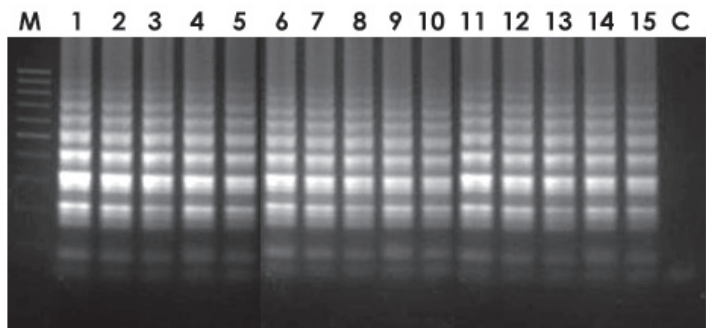

Fig. 5. Detection of PYMoV through loopmediated isothermal amplification (LAMP) assay. Lane M: Marker; lanes 115: test samples and lane C: healthy plant

\section{Management}

Production and use of virus-free planting material

In absence of the resistant variety against viruses in black pepper, the current method available for management of the disease involves production and use of virus-free certified planting materials (Bhat et al. 2010). Virus-free mother plants in different varieties can be identified by testing apparently healthy plants through either PCR or LAMP assays described above. In addition recently, in vitro PYMoV elimination in six varieties of black pepper through somatic embryogenesis was reported. Matured berries collected from PYMoV infected black pepper plants were used as explants for somatic embryogenesis (Fig. 6) (Nair \& Gupta 2006; Sasi \& Bhat 2017). The regenerated and hardened plants obtained from the somatic embryos when tested for PYMoV, $55-100 \%$ of plants were free from PYMoV. Further, complete PYMoV elimination was obtained when somatic embryos were pre-treated with antiviral agent, ribavirin @20 mg ml-1 before regeneration. Sasi \& Bhat (2018) also reported elimination of PYMoV from infected black pepper plants through meristem-tip culture and complete elimination of the virus was obtained when meristem-tip culture was combined with chemotherapy. 


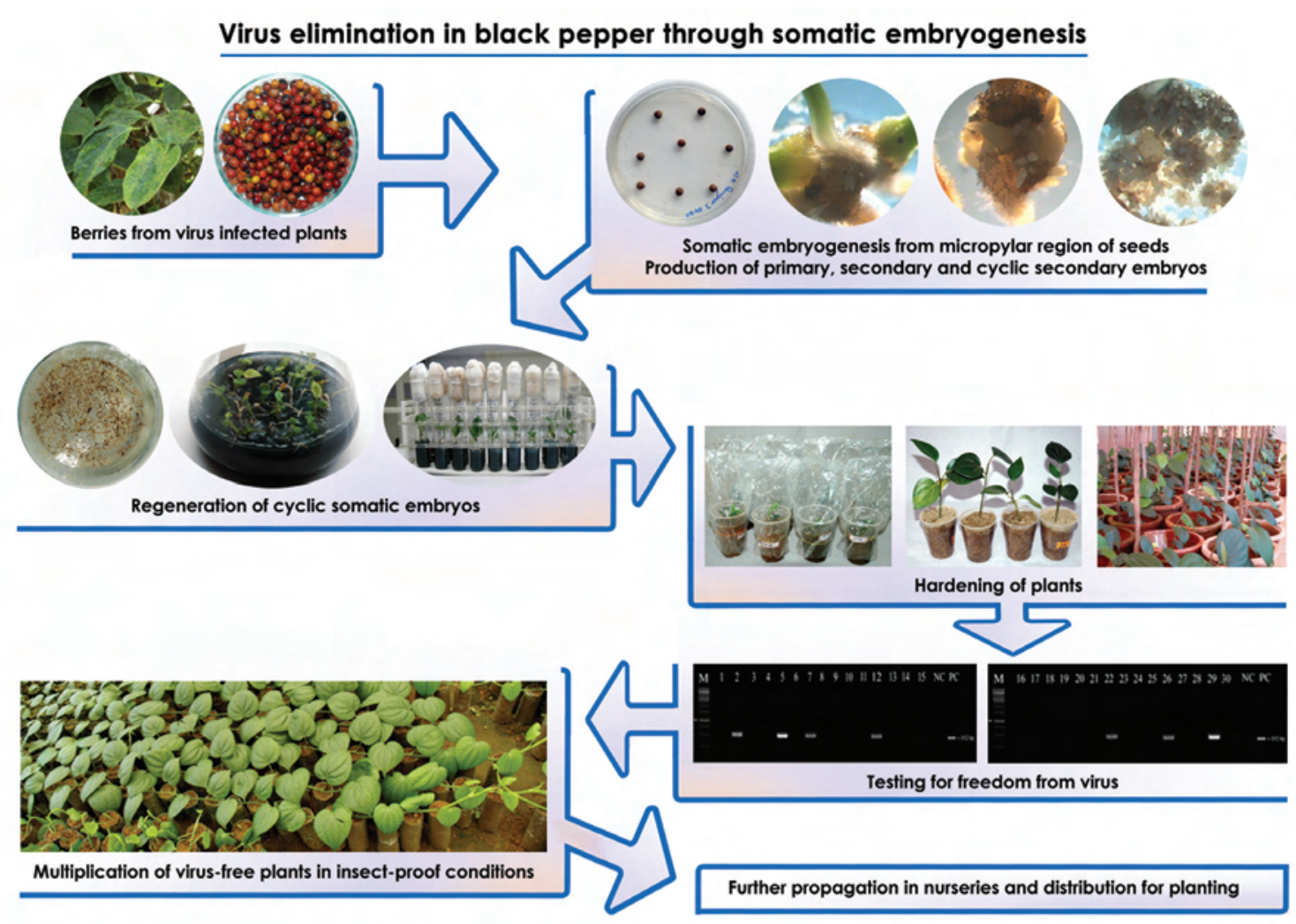

Fig. 6. Flow diagram showing steps in the production of virus-free plants through somatic embryogenesis

Thus, ideally it is important to establish a mother block with virus-free planting materials from certified virus-free high-yielding source plants of known elite variety or using virus-free plants obtained through somatic embryogenesis or meristem tip culture. The mother block should be maintained virus-free by adopting necessary measures and should be protected as well as monitored regularly for viruses using reliable sensitive tools such as PCR or LAMP. Disease-free planting materials collected from mother block are then multiplied in nurseries under protected condition with regular monitoring. Nursery plants also have to be monitored periodically for pathogens and regular rouging of diseased plants should be carried out whenever noticed. The pathogenfree stocks from nurseries are then multiplied in secondary nurseries or used for commercial planting.
Integrated management in the field

In general, as long as the vines are yielding farmers are not willing to sacrifice the vines even if they are infected by viruses especially when the crop is fetching higher price in the market. Hence farmers need to be educated about the symptoms and management of the disease. As the disease spread is primarily through planting materials, farmers should be advised not to take planting materials from virus infected plants for new planting.

The infection in plants may vary from apparently healthy, mild, moderate and severe. Studies have clearly showed that severe symptoms are seen in plants that are subjected to abiotic stresses such as nutrition and high temperature $\left(35^{\circ} \mathrm{C}\right)$. Studies of Srinivasan et al. (2017) showed that the mild and moderately infected plants can be revived. Severely infected 
plants show severe deformation of leaf, reduction in leaf size and internodal length leading to severe stunting of plants and poor yield. It is uneconomical to retain such severely infected plants; they should be removed and burnt or buried deep in soil. To revive and sustain the health and yield of the mild/ moderately virus infected plants, the recommendations (Srinivasan et al. 2017) are as follows:

- Correct the soil acidity by application of amendments like lime or dolomite, based on the soil test.

- $\quad$ Apply farm yard manure (FYM) @10-15 $\mathrm{kg}$ per standard.

- Apply site-specific NPK application (dosage may vary) based on the soil test.

- Apply black pepper specific PGPR consortia \& Trichoderma, twice (June \& September) either by fortifying with FYM (and applied 10-15 kg) or as drenching (2-3 litres per standard).

- Apply micronutrient (IISR Black pepper special) mixture on leaves @5 g/litre twice, after spike emergence during May-June and after spike setting during AugustSeptember.

Not only the individual nutrient supply or concentration in soil or leaf, but the combined effect of each nutrient and its balanced supply influences proper uptake and its utilization. Hence, location/ site-specific crop management programmes should form the basis for balanced nutrient application and need-based foliar supplementations for sustaining the health and yield of the black pepper plants.

\section{Viral diseases of cardamom}

\section{Occurrence and symptoms}

Mosaic (Katte or marble) disease

Katte or mosaic or marble disease incited by Cardamom mosaic virus (CdMV) is one of the important production constraints of cardamom in Guatemala, Sri Lanka and India (Uppal et al. 1945; Dimitman 1981; Dimitman et al. 1984; Gonsalves et al. 1986). In India, the mosaic disease is widely distributed in all cardamom cultivating regions with 0.01 to $99 \%$ incidence (Uppal et al. 1945; Mayne 1951; Venugopal 2002). Recent surveys undertaken to revisit the status of mosaic disease in major cardamom growing states of India indicated that, the incidence ranged from 0 to $85 \%$ with a higher incidence and severity in Karnataka (Biju et al. 2010). Yield loss due to the disease invariably depends on time of infection. If the plant is infected at the young stage, the loss will be almost $100 \%$. However, delayed infection leads to gradual decline in productivity. Higher crop losses $(10-60 \%$, $26-91 \%$ and $82-92 \%$ during first, second and third year) was reported in cardamom-areca mixed cropping system compared to monocrop conditions $(38,62$ and $68.7 \%$ for the first, second and third year of infection) (Varma 1962; Venugopal \& Naidu 1987; Venugopal 1995). In general, complete decline of the plants occur within 3 to 5 years of infection.

The symptoms induced by CdMV include; prominent, discontinuous yellowish stripes radiating from the midrib to the margin on young leaves (Fig. 7a). The size of leaves gets reduced progressively and the plant looses vigour and remains stunted. Later, mottling develops on leaf sheaths. Immature plants when infected rarely produce panicles and set fruits. Whereas, older plants may produce a few lean crops. Variation in symptoms manifested could be attributed to variations in virus strains involved and prevailing environmental conditions in a particular geographical location. Being systemic, the disease consequently invades all the tillers in the clump and eventually the plants produce short, slender tillers with few short panicles in the advanced stages of disease development (Venugopal 2002; Biju et al. 2010; Siljo et al. 2013).

\section{Chlorotic streak}

Chlorotic streak though initially reported from Sirsi taluk of Karnataka, recent surveys revealed its widespread prevalence in major 

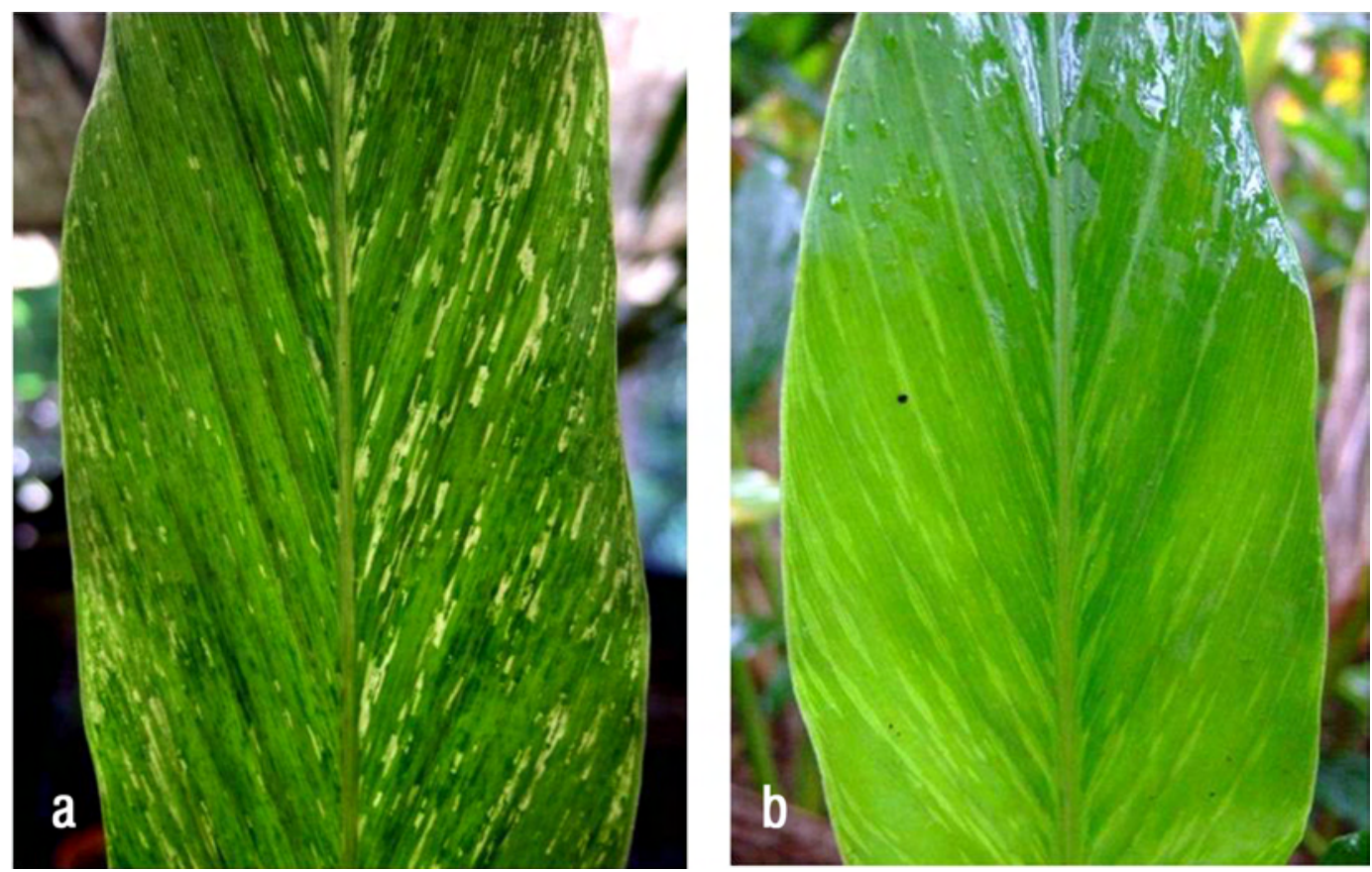

Fig. 7. Symptoms induced by Cardamom mosaic virus (CdMV) (a) and Banana bract mosaic virus (BBrMV) (b) on cardamom

cardamom cultivating tracts of Karnataka and Kerala. Of the 49 locations comprising of 77 plantations surveyed, the disease incidence ranged from $0-15 \%$, the highest being recorded in Vythiri taluk of Wayanad, Kerala. The disease is characterized with the formation of spindleshaped intravenous streaks along the veins and midribs (Fig. 7b). The streaks subsequently join together imparting yellow or light green colour to the veins. The petiole and pseudostem of infected plants also show spindle-shaped mottling. As disease advances, number of tillers produced in the infected plants gets reduced. As chlorotic streaks are the characteristic feature, the disease was named as chlorotic streak (Siljo et al. 2012).

\section{Causal viruses}

\section{Mosaic (Katte or marble) disease}

Earlier reports indicated that, a flexuous rod shaped virus with dimensions $650 \times 10-12 \mathrm{~nm}$ resembling Potyvirus as the probable causal agent of katte (Naidu et al. 1985). Later in Guatemala too similar kind of flexuous rod shaped virus particles were observed in diseased plants (Dimitman 1981; Dimitman et al. 1984). Further, presence of pinwheel type inclusion bodies in the cytoplasm of infected plants confirmed the association of a Potyvirus with mosaic disease (Gonsalves et al. 1986). Serological studies indicated that, the virus is related to Papaya ring spot virus, Zucchini yellow mosaic virus, Cowpea aphid-borne mosaic virus and Bean common mosaic virus. However, based on the nucleotide sequence of the coat protein $(\mathrm{CP})$ gene and 3' untranslated region ( 3 ' UTR), the causal virus shown to belong to the genus Macluravirus of the family Potyviridae (Jacob \& Usha 2001). A comparative analysis of six symptomatologically distinct CdMV isolates representing different agro-ecological regions was carried out by analyzing coat protein gene sequences. The identity in the coat protein sequences among isolates ranged from $74.8 \%$ to $99.3 \%$ and $80.9 \%$ to $99.2 \%$ at nucleotide and amino acid levels, respectively. Subsequently, the isolates were delineated into three distinct groups based on percent nucleotide identities in which the isolates originating from Karnataka (except for the Sirsi isolate) were clustered into one group whereas Kerala isolates represented the other group. Phylogenetic analysis based on multiple 
sequence alignment further confirmed grouping of the isolates on percent identity criterion (Siljo et al. 2013).

\section{Chlorotic streak}

Infected leaf samples showed presence of flexuous rod shaped particles resembling Potyvirus when observed in leaf dip preparation under electron microscope. Further, employing reverse transcription - polymerase chain reaction with primers targeting the conserved regions ['WCIEN' and Poly (A)] specific to Potyvirus genus revealed that, the causal virus is close to the species, Banana bract mosaic virus (BBrMV). Subsequently, confirmatory studies were undertaken by RT-PCR amplification using primers targeting the coat protein gene and 3' untranslated region of the virus followed by sequencing. The coat protein gene sequences of six isolates of BBrMV infecting cardamom from different regions of India showed an identity of $97-99 \%$ and $96-99 \%$ at nucleotide and amino acid levels, respectively. Sequence analysis of all available BBrMV isolates infecting banana and cardamom showed an identity ranging from $94-100 \%$ and $95-100 \%$ at nucleotide and amino acid sequence levels, respectively. Six BBrMV-Banana isolates of Indian origin exhibited a higher nucleotide similarity with BBrMV-Cardamom isolates (9799\%) while, BBrMV-Banana isolates representing Thailand, Philippines, Western Samoa, Vietnam isolates shared 94-96.8\% identity with BBrMV-Cardamom isolates (Siljo et al. 2012). The complete genome sequence of BBrMV-cardamom revealed that it has 9708 nucleotides excluding poly (A) tail and has the genome organization that is similar to that of BBrMV isolates infecting banana and flowering ginger (Alpinia purpurata) (Bhat et al. 2018). The virus has a single open reading frame of 9372 nucleotides that encodes for a polypeptide of 3124 amino acids which is later cleaved into ten matured proteins. The length and arrangements of different proteins in BBrMVCardamom was similar to other BBrMV isolates except for the P1 protein that showed a single amino acid deletion. Comparison with three available complete genome sequences revealed that, BBrMV-Cardamom isolate is more closer to BBrMV-Banana isolate from India (BBrMVTRY) (96.7\% identity) than to BBrMV- Banana isolate from Philippines and flowering ginger isolates from USA (94.5\%). Analysis of polyprotein and their individual proteins also showed close identity of BBrMV-Cardamom and BBrMV-TRY. Further, phylogenetic analysis also suggested that BBrMV-Cardamom isolate is closely related to other BBrMV isolates (Bhat et al. 2018).

\section{Transmission}

\section{Mosaic (Katte or marble) disease}

Initially banana aphid (Pentalonia nigronervosa Coq) was shown to transmit the CdMV nonpersistently in cardamom (Uppal et al. 1945; Varma \& Kapoor 1958). Later 13 aphid species (Aphis craccivora, A. rumicis, A. nerii, A. gossypii, Brachycaudus helichrysi, Greenidia artocarpi, Macrosiphum pisi, M. sonchi, M. rosaeformis, Schiazaphis cyperi, P. nigronervosa f. typica and $P$. nigronervosa f. caladii) were also shown to transmit the virus experimentally from infected to healthy cardamom (Rao \& Naidu 1974). Studies have shown that, P. nigronervosa f. caladii breeds on cardamom, Colocasia and Caladium whereas, P. nigronervosa f. typica breeds on Musa and related genera (Siddappaji \& Reddy 1972; Venugopal 1995). Later based on DNA sequences of mitochondrial cytochrome oxidase (subunit-I) and nuclear elongation factor $1 \alpha$ in combination with morphometric parameters, $P$. nigronervosa f. caladii was restored to full species status as $P$. caladii (Foottit et al. 2010). Both nymphal and adult stages are able to transmit the virus though efficiency of transmission increases with age of the vector and adult; alate and apterous forms are most efficient transmitters. In plantations, the aphids are prevalent throughout the year, although a decline occurs during monsoon. The migrating population was found to be the maximum during January-February, while the populations of alate vectors were found higher during November-May. The primary sources of inoculum include; infected plants and volunteers in disease affected plantations. 
Under field conditions, primary disease spread is mediated through alate viruliferous vectors is random while, the secondary spread which occurs at a lower rate is primarily internal and concentrated within a radius of $40 \mathrm{~m}$ (Deshpande et al. 1972). The incubation period which ranges from 20-114 days is directly affected by variations in weather factors and the symptom expression is significantly influenced by growth stage of the plants. Symptom expression is early during active phase of plant growth (May to November), while the expression is delayed due to prolonged incubation period during December to March. The symptoms develops on young seedlings (of 3-4 leaf stage) within 15-20 days of inoculation whereas, adult plants requires 30-40 days (Naidu \& Venugopal 1989). Seed transmission studies of CdMV in the cultivar Njallani Green Gold indicated that, though the virus was present in the seeds, seedlings raised from the seeds did not show any symptoms and absence of the virus in the seedlings was confirmed through RT-PCR test. This also suggests that, though the virus is seed-borne it is not seed transmitted.

\section{Chlorotic streak}

BBrMV is known to be transmitted nonpersistently by aphids in other host species like banana and flowering ginger (Alpinia purpurata). However, the role of aphids in transmitting BBrMV in cardamom has not been proven yet. The other major means would be through the use of infected planting materials.

\section{Detection and diagnosis}

Mosaic (Katte or marble) disease

\section{Enzyme linked immunosorbent assay (ELISA)}

Purification of CdMV particles from cardamom (Gonsalves et al. 1996) and detection of the virus through direct antigen coated (DAC) and double antibody sandwich ELISA systems were reported (Saigopal et al. 1992).

Reverse transcription-polymerase chain reaction (RTPCR)

Isolation of total RNA from cardamom and reverse transcription-PCR (RT-PCR) for the detection of CdMV was reported. Sequencing coat protein and 3' UTR regions of biologically distinct isolates of CdMV representing diverse geographical locations of Karnataka and Kerala revealed the existence of different strains of the virus. The sequence of strains varied mainly at the N-terminal region of coat protein (Jacob et al. 2003). Hence, primers designed to the conserved region of the coat protein present in all isolates are needed to detect all isolates of the virus. Subsequently, a RT-PCR assay for the detection of CdMV using primers designed to the conserved region of the coat protein was developed and its utility was shown by testing large number of samples drawn from different agro-climatic regions (Fig. 8) (Biju et al. 2010).

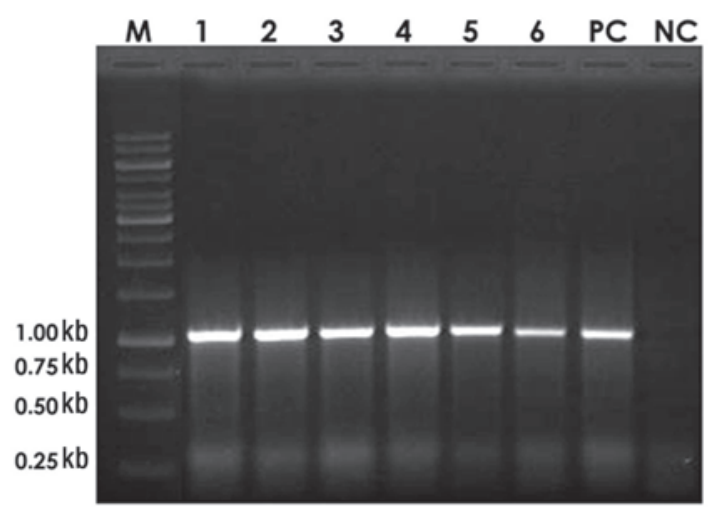

Fig. 8. RT-PCR assay for detection of the CdMV in cardamom plants. Lane M: DNA molecular size markers; Lanes 1-6: RT-PCR products from test plants; Lane PC: positive (infected) control and Lanes NC: negative (healthy) control

Real -time reverse transcription polymerase chain reaction (Real-time RT-PCR)

A SYBR Green based real-time RT-PCR was reported for the detection of CdMV (Siljo et. al. 2014) (Fig. 9). A standard curve was developed to quantify the virus load based on the $\mathrm{Ct}$ values obtained by subjecting different serially diluted virus coat protein region. The sensitivity of the assay for CdMV was determined to be 16 copies which were 1000 times higher than the conventional RT-PCR. Further, real-time RT-PCR assay was verified for its ability to detect large number of samples 
originating from different cardamom cultivating tracts of South India.

\section{Chlorotic streak}

Reverse transcription - polymerase chain reaction (RTPCR)

Protocol for RNA isolation and RT-PCR for detecting BBrMV in cardamom plants and its subsequent validation by testing large number of samples was reported (Siljo et. al. 2012).

\section{Real-time RT-PCR}

A one-step real-time RT-PCR based on SYBR Green was developed for the detection of BBrMV (Siljo et. al. 2014) (Fig.10). The sensitivity of the assay was estimated to be 10 copies which were 1000 times higher than the conventional RT-PCR. The usefulness of the assay was proven by its ability to detect the virus in samples collected from different cardamom growing regions.

Reverse transcription loop-mediated isothermal amplification (RT-LAMP)

A simple, sensitive and rapid assay based on reverse transcription loop-mediated isothermal amplification (RT-LAMP) was reported for the detection of the BBrMV infecting cardamom (Siljo \& Bhat 2014). The various components and their optimum concentration, temperature and time required for the RT-LAMP assay were determined. The results of the RT-LAMP assay was judged visually by checking turbidity and green fluorescence (induced by adding manganese chloride and calcein under UV light) in the reaction tube and also by agarose gel electrophoresis (Fig. 11). The sensitivity of RT-LAMP assay was 100 times higher than that for conventional RT-PCR and on par with that for real-time RT-PCR. The suitability of the assay was confirmed by testing more number of samples of cardamom plants from different cardamom-growing tracts in Kerala.

\section{Management}

Use of healthy planting material and accurate identification of the viruses involved are inevitable components to formulate an integrated disease management package. Large- scale multiplication and planting of virus-free planting material plays a vital role in eliminating viral diseases of small cardamom even from endemic regions. Several strategies have been developed and recommended to ward-off the disease from nurseries as well as plantations. The nurseries should be established in isolated locations and the nucleus planting material should be obtained from disease-free plantations (Venugopal 1995). Early detection of the viruses using reliable and sensitive nucleic acid-based techniques such as RT-PCR, real-time RT-PCR, RT-LAMP would enable to identify disease-free healthy mother genotypes for subsequent propagation (Biju et al. 2010; Siljo \& Bhat 2014; Siljo et al. 2014). Volunteers grown out from the remnants of infected plants could serve as potential primary sources of the viruses and could facilitate subsequent spread of disease in the plantations. Rouging and destruction of volunteers and its complete elimination in the vicinity of nurseries, particularly in the endemic areas are imperative for the production of virus-free planting materials. Regular monitoring, tracing out and destruction of infected plants and collateral hosts (like Colocasia and Caladium), which may act as breeding sites of vectors are indispensable in managing viral diseases of cardamom. Chemical control measures are considered to be ineffective in managing viral diseases owing to the nonpersistent or semi-persistent modes of transmission of viruses by the vectors (Venugopal 2002). Spraying recommended insecticides after undertaking trashing operation increases the efficacy of application and controls the vector to a greater extent. Extracts from several plant species including neem, Acorus calamus, Annona squamosa and Lawsonia inermis were found to adversely affect breeding potential of aphids (Mathew et. al. 1999). Entomopathogens like Beauveria bassiana, Verticillium chlamydosporium and Paecilomyces lilacinus are reported to be promising in suppressing aphid population (Mathew et al. 1998). Natural katte escape (NKE-12) which exhibited immune reaction to katte disease was released as IISR Vijetha and recommended for cultivation in endemic areas of 

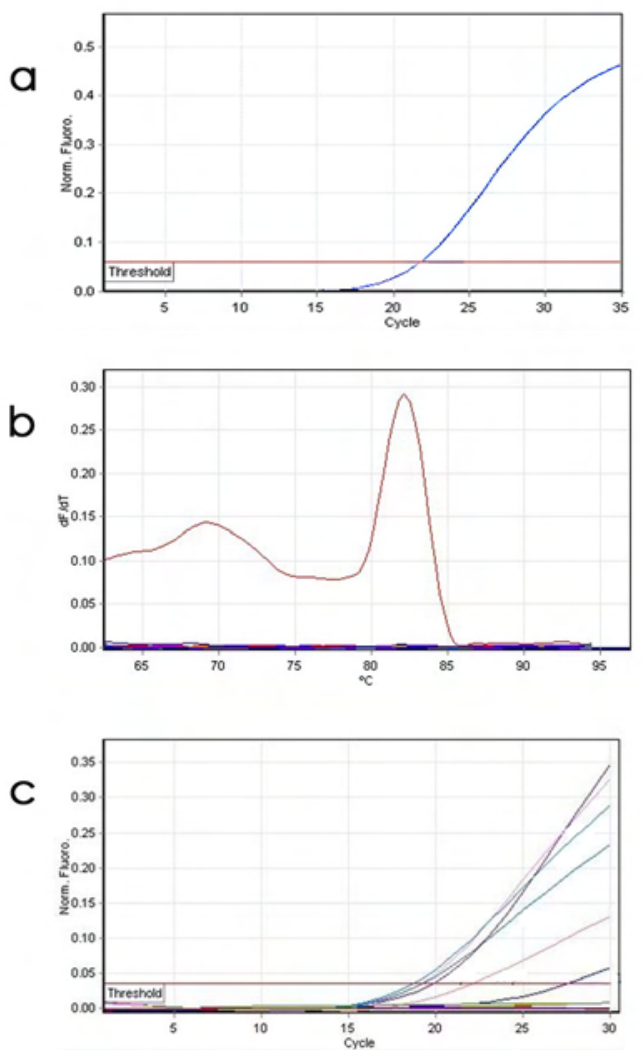

Fig. 9. Development of real-time RT-PCR assay for the detection of CdMV in cardamom (a) Amplification curve obtained with known infected plant (b) melt curve analysis of the same product (c) amplification curves obtained with different field test samples
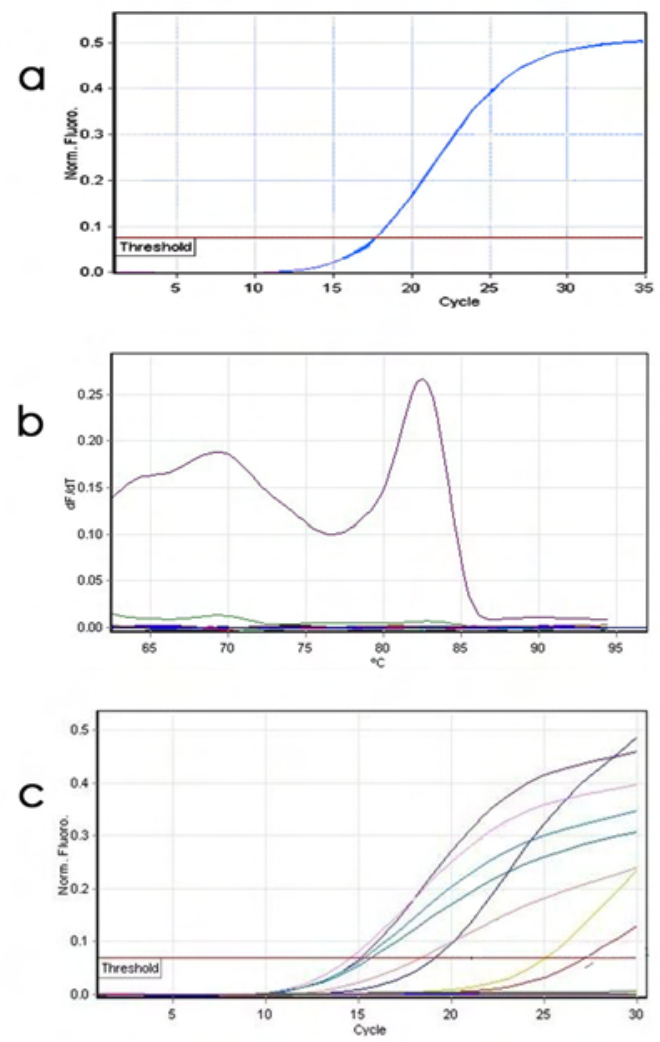

Fig. 10. Development of real-time RT-PCR assay for the detection of BBrMV in cardamom (a) Amplification curve obtained with known infected plant (b) melt curve analysis of the same product (c) amplification curves obtained with different field test samples

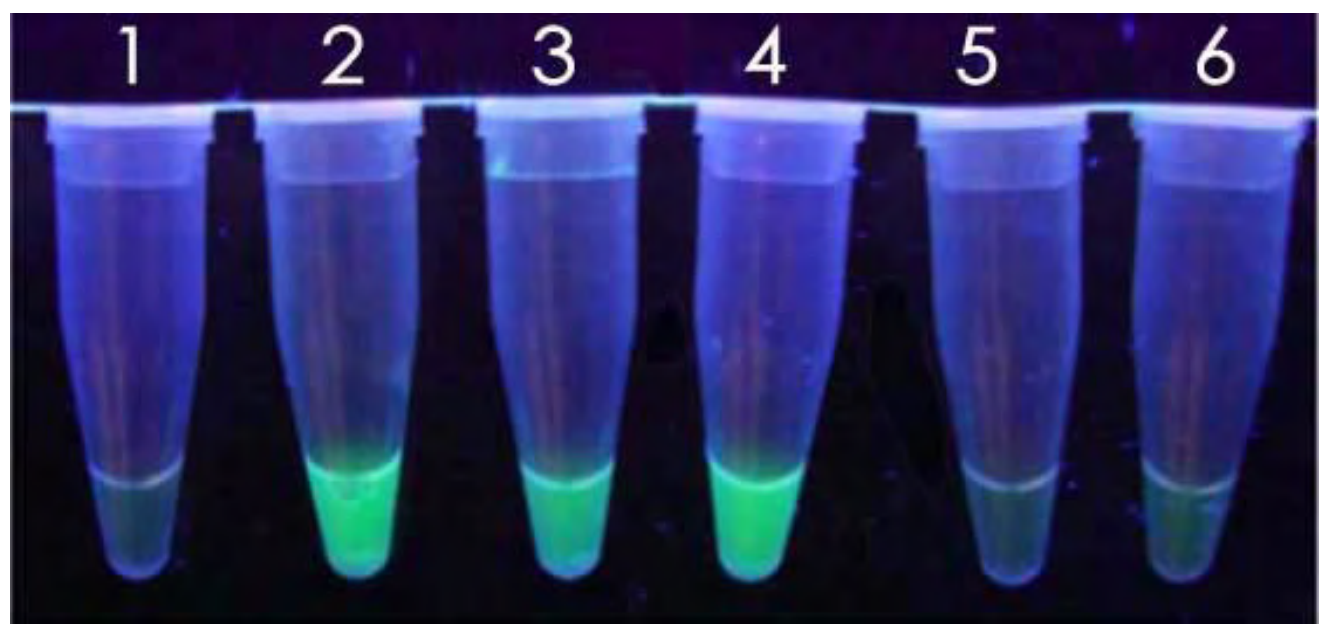

Fig. 11. Visual detection of the presence of BBrMV in cardamom through green fluorescence under UV light in reverse transcription loop-mediated isothermal amplification (RT-LAMP) assay 
katte disease (Venugopal 1999). A successful disease management strategy depends primarily on early detection of the causal virus in the plants even at low copy numbers and at asymptomatic incubation stage. In light of this, combinations of strategies need to be formulated and adopted meticulously for successful management of viral diseases in cardamom.

\section{References}

Bhat A I, Devasahayam S, Sarma Y R \& Pant R P 2003 Association of a Badnavirus in black pepper (Piper nigrum L.) transmitted by mealy bug (Ferrisia virgata) in India. Curr. Sci. 84: 1547-1550.

Bhat A I, Hareesh P S \& Madhubala R 2005a Sequencing of coat protein gene of an isolate of Cucumber mosaic virus infecting black pepper (Piper nigrum L.) in India. J. Plant Biochem. Biotechnol. 14: 37-40.

Bhat A I, Devasahayam S, Hareesh P S, Preethi N \& Thomas T 2005b Planococcus citri (Risso) an additional mealybug vector of Badnavirus infecting black pepper (Piper nigrum L.) in India. Entomon. 30: 85-90.

Bhat A I, Devasahayam S, Venugopal M N \& Suseela Bhai R 2005c Distribution and incidence of viral diseases of black pepper in Karnataka and Kerala, India. J. Plant. Crops 33: 59-64.

Bhat A I \& Siju S 2007 Development of a single tube multiplex RT-PCR for the simultaneous detection of Cucumber mosaic virus and Piper yellow mottle virus associated with stunt disease of black pepper. Curr. Sci. 93: 973-976.

Bhat A I, Siljo A, Jiby M V, Thankamani C K \& Mathew P A 2009 Polymerase chain reaction (PCR) based indexing of black pepper (Piper nigrum L.) plants against Piper yellow mottle virus. J. Spices Arom. Crops 18: 28-32.

Bhat A I, Anandaraj M \& Parthasarathy V A 2010 Diagnostics for production of disease - free planting materials in vegetatively propagated spices. In: Souvenir released during National conference on Production of Quality Seeds and Planting Material Health Management in Horticultural Crops (pp.171-178). 11-14 March 2010, New Delhi.
Bhat A I, Siljo A \& Deeshma K P 2013 Rapid detection of Piper yellow mottle virus and Cucumber mosaic virus infecting black pepper (Piper nigrum) by loop-mediated isothermal amplification (LAMP). J. Virol. Methods 193: 190-196.

Bhat A I \& Siljo A 2014 Detection of viruses infecting black pepper by SYBR Greenbased real-time PCR assay. J. Plant Pathol. 96: 105-109.

Bhat A I, Sasi S, Revathy K A, Deeshma K P \& Saji K V (2014) Sequence diversity among Badnavirus isolates infecting black pepper and related species in India. Virus Dis. 25: 402-407.

Bhat A I, Pamitha, N S, Gopika A \& Biju C N 2018 Complete genome sequencing of Banana bract mosaic virus isolate infecting cardamom revealed its closeness to banana infecting isolate from India. Virus Dis. DOI 10.1007/ s13337-018-0443-7.

Biju C N, Siljo A \& Bhat A I 2010 Survey and RTPCR based detection of Cardamom mosaic virus affecting small cardamom in India. Indian J. Virol. 21: 148-150.

de Silva D P P, Jones P \& Shaw M W 2001 Isolation, purification and identification of Cucumber mosaic virus (CMV) in Sri Lanka on black pepper (Piper nigrum L.). Sri Lankan J. Agri. Sci. 38: 17-27.

de Silva D P P, Jones P \& Shaw M W 2002 Identification and transmission of Piper yellow mottle virus and Cucumber mosaic virus infecting black pepper (Piper nigrum L.) in Sri Lanka. Plant Pathol. 51: 537-545.

Deeshma K P \& Bhat A I 2015 Complete genome sequencing of Piper yellow mottle virus infecting black pepper, betelvine and Indian long pepper. Virus Genes 50: 172-175.

Deeshma K P \& Bhat A I 2014 Further evidence of true seed transmission of Piper yellow mottle virus in black pepper (Piper nigrum L.). J. Plantn. Crops 42: 289-293.

Deshpande R S, Siddappaji C \& Vishwanath S 1972 Epidemiological studies of Katte disease of cardamom. Mysore J. Agri. Sci. 6: 4-9.

Dimitman J E 1981 An aphid transmitted virus of cardamom in Guatemala. Phytopathol. 71: 104-105. 
Dimitman J E, Floras A \& Nikoloff J A 1984 Cardamom mosaic - a member of the potyvirus group in Guatemala. Phytopathol. 74: 844.

Foottit R G, Maw H E L, Pike K S \& Miller R H 2010 The identity of Pentalonia nigronervosa Coquerel and P. caladii van der Goot (Hemiptera: Aphididae) based on molecular and morphometric analysis. Zootaxa. 2358: 25-38.

Gonsalves D, Trujillo E \& Hoch H C1986 Purification and some properties of a virus associated with cardamom mosaic, a new member of the potyvirus group. Plant Dis. 70: 65-69.

Hany U, Adams I P, Glover R, Bhat A I \& Boonham N 2014 The complete genome sequence of Piper yellow mottle virus (PYMoV). Arch. Virol. 159: 385-388.

Hareesh P S, Madhubala R \& Bhat A I 2006 Characterization of Cucumber mosaic virus infecting Indian long pepper (Piper longum L.) and betel vine (Piper betle L.) in India. Indian J. Biotechnol. 5: 89-93.

Hareesh P S \& Bhat, A I 2008 Detection and partial nucleotide sequence analysis of Piper yellow mottle virus infecting black pepper (Piper nigrum L.) in India. Indian J. Virol. 19: 160167.

Hareesh P S \& Bhat A I (2010) Seed transmission of Piper yellow mottle virus in black pepper (Piper nigrum L.). J. Plantn. Crops 38: 62-65.

Jacob T \& Usha R 2001 3'-terminal sequence of RNA genome of Indian isolate of Cardamom mosaic virus, a new member of the genus Macluravirus of Potyviridae. Virus Genes 23: 81-88.

Jacob T, Jebsingh T, Venugopal M N \& Usha R 2003 High genetic diversity in the coat protein and 3' untranslated regions among geographical isolates of Cardamom mosaic virus from South India. J. Biosci. 28: 589-595.

Lockhart B E L, Kirtisak K A, Jones P, Padmini D S, Olsziewski N E, Lockhart N, Nuarchan D \& Sangalang J 1997 Identification of Piper yellow mottle virus, a mealybug transmitted Badnavirus infecting Piper spp. in southeast - Asia. European J. Plant Pathol. 103: 303311.
Mathew M J, Saju K A \& Venugopal M N 1998 Efficacy of entomogenous fungi on biological suppression of Pentalonia nigronervosa f. caladii Van der Goot of cardamom (Elettaria cardamomum Maton). J. Spices Arom. Crops 7: 43-46.

Mathew M J, Venugopal M N \& Saju K A 1999 Field evaluation of certain biopesticides in comparison with monocrotophos against cardamom aphid, vector of katte and kokke kandu diseases of cardamom (Abstr.). In: National Symposium on Biological Control of Insects in Agriculture, Forestry, Medicine and Veterinary Science, 21-22 January, 1999, Bharathiar University, Coimbatore, p.87.

Mayne W W 1951 Cardamom cultivation in South India. ICAR Bull. 50: 87.

Naidu R, Venugopal M N \& Rajan P 1985 Investigations on strainal variation, epidemiology and characterization of ' $k a t t e$ ' virus agent of small cardamom. Final Report of Research Project, Central Plantation Crops Research Institute, Kasaragod, Kerala, India.

Naidu R \& Venugopal M N 1989 Epidemiology of katte virus of small cardamom. Foci of primary disease entry, pattern and gradients of disease entry and spread. J. Plantn. Crops. 16: 267-271.

Nair R R \& Gupta S D 2006 High frequency plant regeneration through cyclic secondary somatic embryogenesis in black pepper (Piper nigrum L.). Plant Cell Rep. 24: 699-707.

Paily P V, Remadevi L, Nair V G, Menon M R \& Nair M R G K 1981 Malformation of leaves in black pepper. J. Plantn. Crops 9: 61-62.

Palukaitis P, Roossinck M, Dietzgen R G \& Francki R I B 1992 Cucumber mosaic virus. Adv. Virus Res. 41: 281-348.

Ravindran P N 2000 Introduction. In: Ravindran P N (Ed.) Black pepper (Piper nigrum) (pp.122). Harwood Academic Publishers.

Ravindran P N 2002 Introduction. In: Ravindran P N \& Madhusoodanan K J (Eds.) Cardamom-The genus Elettaria (pp.1-10.). Taylor and Francis, London and New York.

Revathy K A and Bhat A I 2017 Complete genome sequencing of Cucumber mosaic virus from black pepper revealed rare deletion in the 
methyltransferase domain of 1a gene. Virus Dis. DOI 10.1007/s13337-017-0386-4.

Rao D G \& Naidu R 1974 Additional vectors of katte disease of small cardamom. Indian J. Horti. 31: 380 - 381.

Saigopal D V R, Naidu R \& Joseph T 1992 Early detection of 'katte' disease of small cardamom through Enzyme Linked Immunosorbent assay (ELISA). J. Plantn. Crops 20 (suppl.): 73 - 75.

Sarma Y R, Kiranmai G, Sreenivasulu P, Anandaraj M, Hema M, Venkatramana M, Murthy A K \& Reddy D V R 2001 Partial characterization and identification of a virus associated with stunt disease of black pepper (Piper nigrum) in South India. Curr. Sci. 80: 459-462.

Siddapaji C \& Reddy D N R N 1972 A note on the occurrence of the aphid (Pentalonia nigronervosa f. caladii Van der Goot (Aphididae: Hemiptera) on cardamom (Elettaria cardamomum Maton). Mysore J. Agri. Sci. 6: 192-195.

Siju S, Bhat A I \& Hareesh PS 2008 Identification and characterization of a Badnavirus infecting betel vine and Indian long pepper. J. Plant Biochem. Biotechnol. 17: 73-76.

Siju S, Madhubala R \& Bhat A I 2007 Sodium sulphite enhances RNA isolation and sensitivity of Cucumber mosaic virus detection by RT-PCR in black pepper. J. Virol. Methods. 141: 107-110.

Siljo A, Bhat A I, Biju C N \& Venugopal M N 2012 Occurrence of Banana bract mosaic virus on cardamom. Phytoparasitica 40: 77-85.

Siljo A, Bhat A I \& Biju C N 2013 Symptomatological and coat protein gene sequence studies suggest high variability in Cardamom mosaic virus isolates occurring in India. J. Spices Arom. Crop. 22: 70-75.

Siljo A \& Bhat A I 2014 Reverse transcription loopmediated isothermal amplification assay for rapid and sensitive detection of Banana bract mosaic virus in cardamom (Elettaria cardamomum). European J. Plant Pathol. 138: 209-214.

Siljo A, Bhat A I \& Biju C N 2014 Detection of Cardamom mosaic virus and Banana bract mosaic virus in cardamom using SYBR Green-based
Reverse Transcription-Quantitative PCR. Virus Dis. 25: 137-141.

Sasi S \& Bhat A I 2017 Optimization of cyclic somatic embryogenesis and assessing genetic fidelity in six varieties of black pepper (Piper nigrum L). J. Med. Plants Stud. 4: 109-115.

Sasi S \& Bhat A I 2018 In vitro elimination of Piper yellow mottle virus from infected black pepper through somatic embryogenesis and meristem-tip culture. Crop Prot. 103: 39-45.

Srinivasan V, Bhat A I, Dinesh R, Ankegowda S J, Hamza S, Biju C N \& Krishnamurthy K S 2017 Rejuvenation of virus affected black pepper plantations through soil and plant health management. Indian J. Arec. Spices Med. Pl. 19: 24-27.

Umadevi P, Bhat A I, Krishnamurthy K S \& Anandaraj M 2016 Influence of temperature on symptom expression, detection of host factors in virus infected Piper nigrum L. Indian J. Expl. Biol. 54: 354-360.

Uppal B N, Varma P M \& Kapoor S P 1945 A mosaic disease of cardamom. Curr. Sci. 14: 208-209.

Varma P M 1962 Control of Katte or Mosaic disease of Cardamom in North Kanara. Arec. J. 13: 79-78.

Varma P M \& Kapoor S P 1958 A mosaic disease of cardamom and its transmission by the banana aphid, Pentalonia nigronervosa Coq. Indian J. Agri. Sci. 28: 95-108.

Venugopal M N \& Naidu R 1987 Effect of natural infection of katte/mosaic disease on yield of cardamom - a case study. In: Proceedings of PLACROSYM-VI (pp. 115 - 119). Oxford and IBH, New Delhi.

Venugopal M N 1995 Viral disease of cardamom and their management. J. Spices Arom. Crops 4: 32-39.

Venugopal M N 1999 Natural disease escapes as sources of resistance against cardamom mosaic virus causing katte disease of cardamom (Elettaria cardamom Maton). J. Spices Arom. Crops 8: 145-151.

Venugopal M N 2002 Viral diseases of cardamom. In: Ravindran P N \& Madhusoodanan K J (Eds.) Cardamom-The genus Elettaria (pp.143-159). Taylor and Francis, New York. 